\title{
PENGARUH SUHU INKUBASI DAN JENIS BAKTERI ASAM LAKTAT TERHADAP KECEPATAN FERMENTASI DAN MUTU ORGANOLEPTIK SOSIS IKAN
}

\author{
Endang Sri Heruwati ${ }^{*}$, Endang Sudariastuti ${ }^{* *}$, dan Ninuk Indriati ${ }^{*}$
}

\begin{abstract}
ABSTRAK
Suatu penelitian untuk melihat pengaruh suhu dan jenis bakteri asam laktat terhadap kecepatan fermentasi dan mutu organoleptik sosis ikan telah dilakukan. Perlakuan jenis bakteri asam laktat yang dipilih adalah (1) bakteri Lactobacillus plantarum, (2) L. fermentum, dan (3) campuran keduanya (1:1), sedangkan perlakuan suhu inkubasi adalah $10^{\circ} ; 20^{\circ}$ dan $30^{\circ} \mathrm{C}$. Pengamatan terhadap jumlah bakteri asam laktat, produksi asam laktat, $\mathrm{pH}$, mutu organoleptik, dan jumlah basa menguap (TVB) dilakukan setiap dua hari selama 8 hari fermentasi.

Hasil penelitian menunjukkan bahwa hingga hari ke-4, pengaruh suhu dan jenis bakteri terhadap kecepatan fermentasi dan mutu organoleptik tampak nyata, tetapi pada hari ke- 6 hanya pengaruh suhu yang nyata. Setelah itu, pengaruh kedua jenis perlakuan sudah tidak terlihat. Pada suhu $10^{\circ} \mathrm{C}$ dan $20^{\circ} \mathrm{C}$ puncak fermentasi berturut-turut terjadi pada hari ke-6 dan ke-4, sementara pada $30^{\circ} \mathrm{C}$, pada hari ke-2 fermentasi telah mencapai maksimum. Walaupun demikian, fermentasi pada $30^{\circ} \mathrm{C}$ tidak disarankan karena nilai TVB telah melampaui ambang batas kesegaran ikan. Meskipun penggunaan campuran bakteri $L$. plantarum dengan $L$. fermentum semula dimaksudkan untuk mengurangi rasa asam, tetapi dari hasil produksi asam laktat, $\mathrm{pH}$, maupun nilai organoleptik ternyata penggunaan campuran bakteri asam laktat tidak berbeda dengan penggunaan bakteri spesies tunggal. Namun demikian bila menggunakan bakteri secara tunggal, sebaiknya menggunakan $L$. plantarum karena $L$. fermentum proses fermentasinya sangat lambat.
\end{abstract}

\section{ABSTRACT: Effect of incubation temperatures and species of lactic acid bacteria on the rate of fermentation and organoleptic quality of fish sausage. By: Endang Sri Heruwati, Endang Sudariastuti, and Ninuk Indriati.}

An experiment was conducted to know the effect of incubation temperatures and kinds of bacteria on the rate of fermentation and organoleptic quality of fermented fish sausage. Two treatments used in this experiment were: species of lactic acid bacteria and temperature of incubation. Species of lactic acid bacteria used were (1) Lactobacillus plantarum, (2) L. fermentum, and (3) the mixture of L.plantarum and L.fermentum (1:1), while the temperatures of incubation were $10^{\circ} ; 20^{\circ}$ and $30^{\circ} \mathrm{C}$. The growth of lactic acid bacteria, production of lactic acid, pH, organoleptic quality, and total volatile bases were assessed every two days for 8 days of fermentation time.

Results of the experiment showed that effect of both treatments on the rate of fermentation and organoleptic quality were significant up to day-4, but at day-6, effect of species of bacteria was no longer assessed. Afterwards, both treatments were not significantly different. At $10^{\circ}$ and $20^{\circ} \mathrm{C}$, fermentation peaks were achieved at day-6 and day-4 respectively, while at $30^{\circ} \mathrm{C}$, the fermentation process gained maximum at day-2. Nevertheless, fermentation at $30^{\circ} \mathrm{C}$ was not recommended since the total volatile bases produced under that treatment was beyond the freshness borderline. Though the use of mixture of L. plantarum and L.fermentum was proposed to reduce the sour taste of the sausage, however, from the production of lactic acid, $\mathrm{pH}$ as well as organoleptic scores points of view, it could be concluded that the use of mixture of lactic acid bacteria was not better than that of single species. However, in using single species, the use of L. plantarum was recommended instead of $L$. fermentum due to the low rate of fermentation of the later species.

KEYWORDS: Lactic acid bacteria, fish sausage, fermentation.

\footnotetext{
Peneliti pada Balai Penelitian Perikanan Laut, Jakarta

**) Pengajar pada Sekolah Tinggi Perikanan, Jakarta
} 


\section{PENDAHULUAN}

Penambahan mikroorganisme dalam pengolahan sosis fermentasi dimaksudkan untuk meningkatkan daya awet dan keamanan produk, serta meningkatkan mutu organoleptik selain mempertahankan nilai gizi produk.

Mikroorganisme yang sering digunakan dalam pembuatan sosis daging adalah bakteri atau jamur dan ragi. Menurut Smith dan Palumbo (1983), beberapa jenis bakteri yang digunakan antara lain Pediococcus ( $P$. cerevisiae dan $P$. pentosaceus); Lactobacillus (L. plantarum dan $L$. brevis); serta Micrococcus (M. varians). Adapun jamur dan ragi yang sering digunakan adalah Penicillium ( $P$. janthinellum, $P$. simplicissium, $P$. cyclopium, $P$. viridicatum), Thamnidium ( $T$. elegans) dan Candida (C. lipolitica). Lactobacillus atau bakteri asam laktat sangat sering digunakan untuk tujuan ini karena lebih cepat memproduksi asam laktat, ataupun karena ia memproduksi bakteriosin yang dapat menghambat pertumbuhan bakteri lain termasuk bakteri patogen. Asam laktat yang terbentuk dari gula yang ditambahkan akan menurunkan $\mathrm{pH}$ dan ini juga akan membuat produk menjadi awet.

Keuntungan lain dari penambahan bakteri asam laktat pada pembuatan sosis adalah kemampuannya untuk menghambat bakteri pembusuk psikotrop yang bersifat gram negatif serta Salmonella typhimurium dan S. dublin (Smith dan Palumbo, 1983), serta dapat pula meng. hambat pertumbuhan bakteri dan pembentukan toksin Clostridium botulinum (Tanaka et al., 1980). Lebih jauh, Baran dan Stevensen (1975) telah membuktikan bahwa penambahan $P$. cerevisiae pada sosis mampu mereduksi 4,5-5,3 siklus $\log$ bakteri $S$. pullorum, 1,5-2,0 siklus log $S$. seftenberg, 1,2-3,6 siklus $\log$ C. perfringens, dan 1,4-2,1 siklus log bakteri $E$. coli.

Bakteri pemfermentasi sering digunakan dalam bentuk campuran dari dua spesies, untuk mendapatkan produk akhir yang lebih disukai konsumen. Sebagai contoh, $P$. cerevisiae digunakan bersama-sama dengan $M$. varians karena $P$. cerevisiae merupakan pembentuk asam laktat yang kuat, sementara M.varians tidak terlalu kuat, namun dapat meningkatkan rasa dan warna produk karena kemampuannya memproduksi katalase. Katalase dapat mendekomposisi peroksida yang sering dihasilkan oleh sosis sebagai akibat aktivitas bakteri atau reaksi oksidasi, yang menyebabkan kerusakan warna. Selain itu, campuran antara $P$. cerevisiae dengan $L$. plantarum sering dimaksudkan untuk menekan pembentukan peroksida, atau memperpendek proses fermentasi.

Bakteri $L$. plantarum seringkali juga digunakan bersama-sama dengan $L$. fermentum karena L. plantarum bersifat homofermentatif sehingga memberikan rasa asam yang tinggi. Pencampuran dengan bakteri $L$. fermentum yang bersifat heterofermentatif dimaksudkan untuk mengurangi rasa asam, di samping untuk mendapatkan aroma lain dari hasil fermentasi (Stanton dan Yeoh, 1977).

Indriati et al. (1994) dalam percobaannya menggunakan campuran bakteri L. plantarum dan L. fermentum dengan maksud untuk memperoleh rasa asam yang disukai konsumen, mendapatkan bahwa pada suhu inkubasi di atas $30^{\circ} \mathrm{C}$, bakteri proteolitik, lipolitik maupun halofilik berkembang dengan cepat. Hal ini akan merugikan, karena ketiga jenis bakteri tersebut sangat potensial untuk menghasilkan produk metabolisme berupa senyawa-senyawa yang mengganggu sifat sensoris produk. Suhu inkubasi yang lebih rendah diperkirakan lebih aman, namun bagaimana kecepatan fermentasi pada suhu rendah belum diketahui, mengingat bakteri asam laktat mempunyai suhu optimum yang berbeda, yaitu $30^{\circ} \mathrm{C}$ untuk $L$. plantarum (Jay, 1978) dan $37^{\circ} \mathrm{C}$ untuk L. fermentum (Frazier dan Westhoff, 1979).

Untuk mengetahui apakah dalam pembuatan sosis fermentasi campuran antara bakteri $L$. plantarum dengan $L$. fermentum lebih baik dibandingkan bila masing-masing jenis bakteri digunakan terpisah, serta untuk mengetahui suhu inkubasi yang lebih menguntungkan, maka dilakukan percobaan pengolahan sosis ikan dengan jenis bakteri dan suhu inkubasi yang berbeda.

\section{BAHAN DAN METODE}

Bahan baku yang digunakan dalam pembuatan sosis ikan adalah ikan jangilus (Istiophorus gladius) yang dibeli dari Pelabuhanratu yang kemudian dikemas dalam es hancuran dan dibawa ke laboratorium Inlitkanlut Slipi di Jakarta dalam keadaan dies. Setelah sampai di laboratorium, ikan dibersihkan, disiangi, dan 
dipisahkan dagingnya, untuk kemudian dihancurkan dengan mesin pencincang.

Adapun bahan pembantu yang ditambahkan adalah tepung tapioka $10 \%$, minyak sayur $3 \%$, garam dapur $3 \%$, gula pasir $2,5 \%$, bubuk lada $0,2 \%$, ketumbar $0,07 \%$, jahe $0,07 \%$, kayu manis $0,06 \%$, bawang putih $0,03 \%$, dan cengkeh $0,05 \%$. Ditambahkan pula es batu sebanyak $2 \%$ selama proses pembuatan adonan untuk mempertahankan suhu adonan tetap rendah.

Daging cincang, tapioka dan minyak sayur dicampurkan, kemudian ditambahkan bumbubumbu yang telah dihaluskan. Selanjutnya campuran semua bahan tersebut digiling menggunakan mesin penggiling. Selama penggilingan ditambahkan es batu. Setelah halus dan rata, adonan dibagi menjadi 3 bagian, masing-masing bagian diberi perlakuan bakteri asam laktat, yaitu L. plantarum, L. fermentum, dan campuran keduanya dengan perbandingan 1:1. Suspensi bakteri yang ditambahkan adalah $2 \mathrm{~mL}$ (dengan jumlah bakteri $10^{8} / \mathrm{mL}$ ) untuk setiap $500 \mathrm{~g}$ adonan.

Setelah diberikan perlakuan, adonan dimasukkan ke dalam selongsong (casing) gelatin dengan diameter $2,5 \mathrm{~cm}$. Sosis kemudian diikat dengan tali benang, masing-masing ikatan sepanjang $10 \mathrm{~cm}$. Selama pemasukan ke dalam selongsong dan pengikatan, sosis selalu diletakkan dalam nampan yang diberi es batu untuk menjaga agar suhu tetap rendah sehingga proses deteriorasi dapat dihambat.

Selesai pengikatan, dilakukan pengasapan menggunakan tempurung kelapa dalam almari asap selama 4 jam pada suhu $50^{\circ} \mathrm{C}$. Kemudian sosis dibiarkan dingin dan dikemas dalam kantong-kantong polietilen untuk disimpan pada suhu inkubasi yang berbeda, yakni $10^{\circ} ; 20^{\circ}$, dan $30^{\circ} \mathrm{C}$. Fermentasi berlangsung selama proses penyimpanan tersebut.

Pengamatan komposisi proksimat dilakukan setelah selesai pengasapan. Di samping itu, contoh diambil setiap 2 hari untuk diamati perubahan kadar air, $\mathrm{pH}$, jumlah basa menguap (TVB), jumlah bakteri asam laktat, dan jumlah asam laktat yang dihasilkan. Jumlah asam laktat dihitung berdasarkan selisih persentase bobot kering asam laktat (dengan titrasi $\mathrm{KOH}$ ) terhadap kadar asam laktat pada awal percobaan. Selain itu juga dicatat perubahan karakteristik organoleptik, khususnya rasa dan kekenyalan, yang diamati oleh 7 orang panelis. Penilaian menggunakan skor 1 sampai dengan 5, dengan nilai 5 untuk rasa dan kekenyalan terbaik.

\section{HASIL DAN PEMBAHASAN}

\section{Karakteristik Sosis Ikan}

Karakteristik sosis ikan setelah selesai pengasapan dan siap untuk diinkubasikan adalah seperti pada Tabel 1. Nilai $\mathrm{pH}$ yang rendah dan jumlah bakteri (bakteri asam laktat dan total bakteri) yang cukup tinggi dalam tabel tersebut menunjukkan bahwa sebenarnya proses fermentasi telah berlangsung walaupun inkubasi belum dimulai. Hal ini mungkin terjadi mengingat proses pemasukan adonan sosis ke dalam selongsong, proses pengasapan, dan pendinginan sebelum sosis diinkubasikan memerlukan waktu yang relatif lama, yaitu sekitar 6 hingga 7 jam. Namun demikian rendahnya nilai organoleptik produk menunjukkan bahwa sosis masih perlu difermentasikan agar mempunyai kekenyalan dan rasa seperti yang diinginkan.

\section{Perkembangan Bakteri Asam Laktat}

Gambar 1 memperlihatkan bahwa perkembangan jumlah bakteri asam laktat secara nyata dipengaruhi oleh perlakuan suhu inkubasi dan jenis bakteri yang ditambahkan. Hingga masa inkubasi hari ke-4, perlakuan campuran bakteri $L$. plantarum dan $L$. fermentum menunjukkan perkembangan bakteri asam laktat yang paling lambat dibandingkan dengan kedua perlakuan lain, namun setelah hari ke 6 dan memasuki hari ke-8 inkubasi, perbedaan tersebut sudah tidak terlihat. Dari gambar tersebut tampak pula bahwa pola perkembangan bakteri asam laktat sangat berbeda menurut suhu. Pada suhu $10^{\circ} \mathrm{C}$, perkembangan bakteri maksimum dari perlakuan bakteri spesies tunggal dicapai pada hari ke-6, sedangkan pada perlakuan spesies campuran, jumlah bakteri masih terus meningkat hingga hari ke-8. Pada $20^{\circ} \mathrm{C}$, perlakuan bakteri spesies tunggal mencapai maksimum pada hari ke-4, sementara spesies campuran pada hari ke-6. Pada $30^{\circ} \mathrm{C}$, ketiga perlakuan telah menunjukkan perkembangan maksimum pada hari ke-2 inkubasi. 
Tabel 1. Karakteristik sosis ikan dengan tiga perlakuan jenis bakteri sebelum inkubasi Table 1. Characteristics of fish sausage using three kinds of bacterial treatment before incubation

\begin{tabular}{|c|c|c|c|}
\hline \multirow{2}{*}{ Parameter } & \multicolumn{2}{|c|}{ Species tunggal (Single species) } & \multirow{2}{*}{$\begin{array}{l}\text { Spesies campuran } \\
\text { (Mixed species) }\end{array}$} \\
\hline & L. plantarum & L.fermentum & \\
\hline Kadar air (moisture) \% & 68.06 & 67.71 & 69.89 \\
\hline Kadar protein $\%$ & 22.72 & 22.80 & 22.80 \\
\hline Kadar lemak (fat)\% & 1.01 & 1.46 & 1.09 \\
\hline Kadar abu $(a s h) \%$ & 2.10 & 2.20 & 2.46 \\
\hline $\mathrm{pH}$ & 5.7 & 5.6 & 5.3 \\
\hline $\begin{array}{l}\text { Jumlah bakt. as.laktat (Lactic acid } \\
\text { bacterial number) (log) }\end{array}$ & 8.18 & 8.19 & 8.59 \\
\hline Jumlah bakteri total (TPC) (log) & 7.68 & 7.77 & 7.92 \\
\hline Nilai organoleptik (Organoleptic score) & 3.0 & 3.0 & 3.0 \\
\hline Jumlah basa menguap (TVB) mgN\% & 21.9 & 22.9 & 20.2 \\
\hline
\end{tabular}

\section{Pembentukan Asam Laktat}

Asam laktat, yang merupakan hasil pemecahan gula oleh bakteri asam laktat, terbentuk dengan kecepatan yang sama dengan perkembangan bakteri asam laktat (Tabel 2). Untuk semua perlakuan suhu, hingga hari ke-4, terlihat pengaruh nyata dari jenis bakteri maupun suhu inkubasi. Mulai hari ke-6, hanya suhu yang berpengaruh terhadap kenaikan asam laktat, sedangkan jenis bakteri tidak. Pada hari ke-8, baik suhu maupun jenis bakteri tidak lagi berpengaruh terhadap kenaikan asam laktat.

Pada suhu $10^{\circ} \mathrm{C}$, puncak pembentukan asam laktat oleh ketiga perlakuan jenis bakteri dicapai pada hari ke-6, demikian pula pada suhu $20^{\circ} \mathrm{C}$, kecuali perlakuan $L$. plantarum yang mencapai puncak pada hari ke-4. Adapun pada suhu $30^{\circ} \mathrm{C}$, ketiga perlakuan telah menghasilkan puncak pembentukan asam laktat pada hari ke-2, walaupun pada suhu tersebut, perlakuan $L$. fermentum tetap menghasilkan asam laktat yang terendah dibandingkan kedua perlakuan jenis bakteri lain. Hal ini dapat dimengerti karena $L$. fermentum mempunyai suhu optimum yang lebih tinggi dibandingkan L. plantarum. Berdasarkan hasil tersebut dapat dikatakan bahwa $L$. fermentum tidak banyak berperan, sedangkan antara perlakuan $L$. plantarum dengan perlakuan spesies campuran tidak berbeda nyata.

\section{Perubahan pH}

Selain asam laktat, parameter lain yang digunakan untuk mengukur aktivitas bakteri asam laktat selama proses fermentasi adalah $\mathrm{pH}$ sosis ikan. Dari hasil pengamatan $\mathrm{pH}$ terlihat bahwa seperti halnya jumlah bakteri asam laktat maupun produksi asam laktat, perubahan $\mathrm{pH}$ sudah terlihat pada hari ke-2, yaitu dari $\mathrm{pH}$ awal 5,305,70 menjadi 4,06-5,11. Pada periode berikutnya, hari ke-4 dan ke-6, pengaruh kedua macam perlakuan sangat nyata, tetapi pada hari ke-8, hanya suhu yang berpengaruh terhadap perubahan $\mathrm{pH}$, sedangkan jenis bakteri tidak (Tabel 3). 

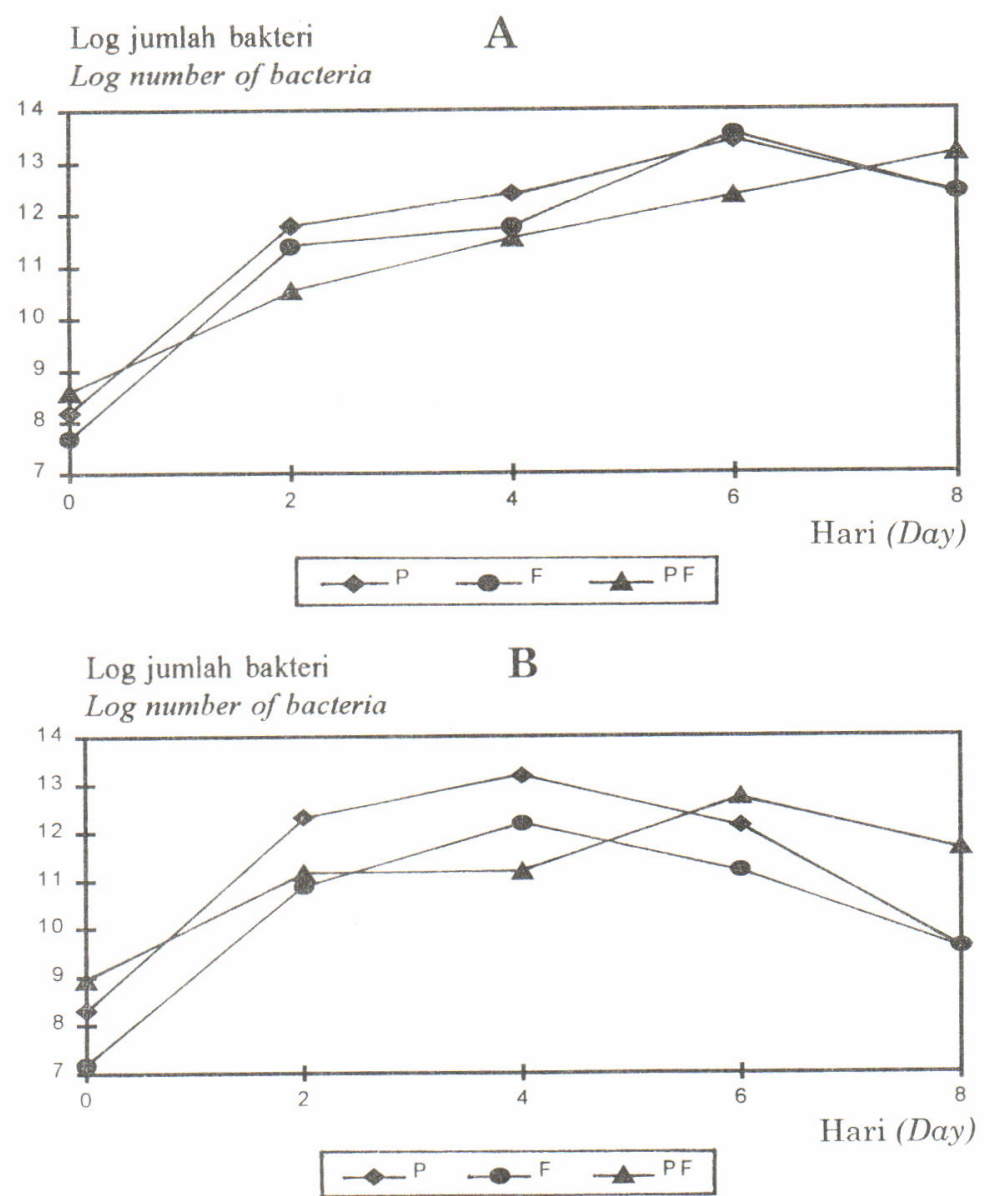

Log jumlah bakteri

C

Log number of bacteria

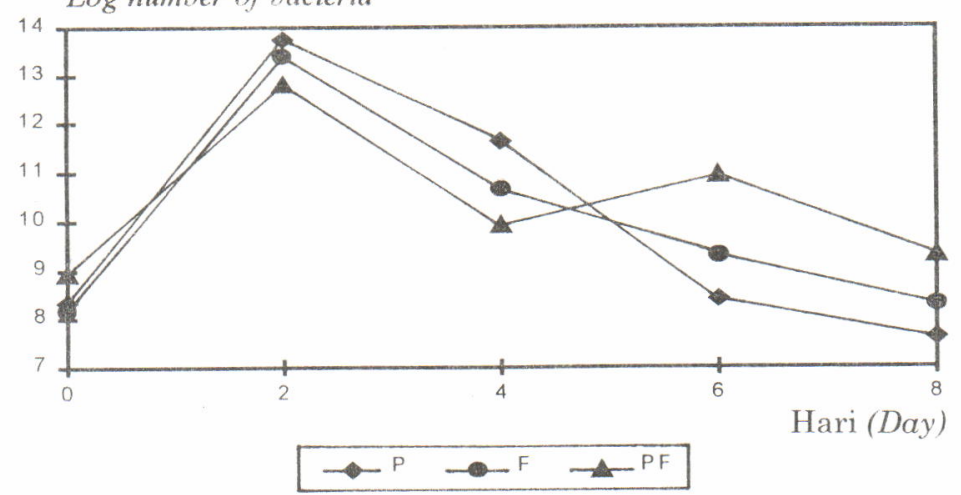

P: L.plantarum, F: L.fermentum, PF: spesies campuran/mixed species

Gambar 1. Perkembangan bakteri asam laktat pada suhu $10^{\circ} \mathrm{C}(\mathrm{A}), 20^{\circ} \mathrm{C}(\mathrm{B})$, dan $30^{\circ} \mathrm{C}(\mathrm{C})$. Figure 1. The growth of lactic acid bacteria at $10^{\circ} \mathrm{C}(\mathrm{A}), 20^{\circ} \mathrm{C}(\mathrm{B})$, and $30^{\circ} \mathrm{C}(\mathrm{C})$. 
Tabel 2. Peningkatan asam laktat selama proses fermentasi sosis ikan (selisih $\%$ bobot kering terhadap kadar aşam laktat pada awal percobaan).

Table 2. Increase of lactic acid during fermentation process of fish sausage (substraction of dry weight bases from the initial day of experiment).

\begin{tabular}{|c|c|c|c|c|}
\hline $\begin{array}{l}\text { Perlakuan } \\
\text { (Treatment) }\end{array}$ & Hari-2 (Day-2) & Hari-4 (Day-4) & Hari-6 (Day-6) & Hari-8 (Day-8) \\
\hline \multicolumn{5}{|l|}{$10^{\circ} \mathrm{C}$} \\
\hline $\mathrm{P}$ & $1.16 \pm 0.01^{\mathrm{a}}$ & $1.16 \pm 0.01^{\mathrm{a}}$ & $2.43 \pm 0.02^{\mathrm{a}}$ & $1.81 \pm 0.94^{\mathrm{a}}$ \\
\hline $\mathrm{F}$ & $0.55 \pm 0.36^{\mathrm{b}}$ & $0.55 \pm 0.36^{\mathrm{b}}$ & $2.14 \pm 0.03^{\mathrm{a}}$ & $1.29 \pm 1.17^{\mathrm{a}}$ \\
\hline $\mathrm{PF}$ & $1.26 \pm 0.06^{\mathrm{a}}$ & $2.47 \pm 0.54^{\mathrm{c}}$ & $3.37 \pm 0.54^{\mathrm{b}}$ & $2.42 \pm 0.02^{\mathrm{a}}$ \\
\hline \multicolumn{5}{|l|}{$20^{\circ} \mathrm{C}$} \\
\hline $\mathrm{P}$ & $1.80 \pm 0.01^{\mathrm{c}}$ & $3.25 \pm 0.1^{\mathrm{d}}$ & $2.64 \pm 0.01^{\mathrm{ac}}$ & $2.31 \pm 0.70^{\mathrm{a}}$ \\
\hline $\mathrm{F}$ & $0.09 \pm 0.02^{\mathrm{d}}$ & $0.73 \pm 0.06^{e}$ & $2.34 \pm 0.02^{\mathrm{c}}$ & $1.74 \pm 0.44^{\mathrm{ab}}$ \\
\hline $\mathrm{PF}$ & $0 \pm 0.02^{\mathrm{e}}$ & $0 \pm 0.01^{\mathrm{f}}$ & $2.54 \pm 0.03^{\mathrm{a}}$ & $1.70 \pm 0.13^{\mathrm{ab}}$ \\
\hline \multicolumn{5}{|l|}{$30^{\circ} \mathrm{C}$} \\
\hline $\mathrm{P}$ & $2.16 \pm 0.06^{f}$ & $1.62 \pm 0.18^{\mathrm{g}}$ & $1.17 \pm 0.01^{\mathrm{d}}$ & $1.43 \pm 0.07^{\mathrm{ab}}$ \\
\hline $\mathrm{F}$ & $1.26 \pm 0.00^{\mathrm{a}}$ & $1.17 \pm 0.05^{\mathrm{h}}$ & $0.42 \pm 1.03^{\mathrm{d}}$ & $0.26 \pm 1.24^{\mathrm{b}}$ \\
\hline $\mathrm{PF}$ & $2.51 \pm 0.01^{\mathrm{g}}$ & $2.12 \pm 0.03^{\mathrm{a}}$ & $1.22 \pm 0.09^{\mathrm{d}}$ & $1.74 \pm 0.00^{\mathrm{ab}}$ \\
\hline
\end{tabular}

P: L. plantarum, F: L.fermentum, PF: spesies campuran (mixed species).

Nilai dalam kolom diikuti huruf superskrip yang sama tidak berbeda nyata pada P:0,05 (Values in column followed by the same superscripts are not significantly different at P:0.05).

Tabel 3. Nilai $\mathrm{pH}$ sosis ikan selama proses fermentasi.

Table 3. $p H$ values of fish sausage during fermentation process.

\begin{tabular}{|c|c|c|c|c|}
\hline $\begin{array}{l}\text { Perlakuan } \\
\text { (Treatment) }\end{array}$ & Hari-2 (Day-2) & Hari-4 (Day-4) & Hari-6 (Day-6) & Hari-8 (Day-8) \\
\hline \multicolumn{5}{|l|}{$10^{\circ} \mathrm{C}$} \\
\hline $\mathrm{P}$ & $4.97 \pm 0.03^{\mathrm{a}}$ & $5.07 \pm 0.01^{\mathrm{a}}$ & $4.60 \pm 0.00^{\mathrm{a}}$ & $4.50 \pm 0.13^{\mathrm{a}}$ \\
\hline $\mathrm{F}$ & $4.93 \pm 0.00^{\mathrm{b}}$ & $4.93 \pm 0.00^{\mathrm{b}}$ & $4.70 \pm 0.03^{\mathrm{b}}$ & $4.51 \pm 0.11^{\mathrm{a}}$ \\
\hline $\mathrm{PF}$ & $5.11 \pm 0.01^{c}$ & $4.81 \pm 0.02^{\mathrm{c}}$ & $4.07 \pm 0.00^{c}$ & $4.54 \pm 0.06^{\mathrm{a}}$ \\
\hline $20^{\circ} \mathrm{C}$ & $4.06 \pm 0.00^{\mathrm{d}}$ & $4.59 \pm 0.03^{\mathrm{d}}$ & $4.59 \pm 0.00^{\mathrm{a}}$ & $4.89 \pm 0.01^{\mathrm{b}}$ \\
\hline $\mathrm{F}$ & $4.58 \pm 0.01^{\mathrm{e}}$ & $4.50 \pm 0.00^{\mathrm{e}}$ & $4.50 \pm 0.01^{\mathrm{d}}$ & $4.57 \pm 0.06^{\mathrm{a}}$ \\
\hline $\mathrm{PF}$ & $4.73 \pm 0.01^{\mathrm{f}}$ & $4.72 \pm 0.00^{\mathrm{f}}$ & $4.61 \pm 0.00^{\mathrm{a}}$ & $4.65 \pm 0.00^{\mathrm{a}}$ \\
\hline \multicolumn{4}{|l|}{$30^{\circ} \mathrm{C}$} & $4.84 \pm 0.08^{\mathrm{b}}$ \\
\hline $\mathrm{F}$ & $4.64 \pm 0.08^{\mathrm{g}}$ & $4.40 \pm 0.00^{\mathrm{g}}$ & $4.77 \pm 0.01^{\mathrm{f}}$ & $4.86 \pm 0.06^{\mathrm{b}}$ \\
\hline $\mathrm{PF}$ & $4.06 \pm 0.00^{\mathrm{d}}$ & $4.20 \pm 0.00^{\mathrm{h}}$ & $4.88 \pm 0.01^{\mathrm{g}}$ & $4.88 \pm 0.02^{\mathrm{b}}$ \\
\hline
\end{tabular}

P: L. plantarum, F: L.fermentum, PF: spesies campuran/ mixed species

- Nilai dalam kolom diikuti huruf superskrip yang sama tidak berbeda nyata pada P:0,05/ Values in column followed by the same superscripts are not significantly different at P:0.05 


\section{Jumlah Basa Menguap (TVB)}

Parameter TVB biasanya digunakan sebagai tolok ukur estimasi tingkat kerusakan ikan pada tahap akhir penyimpanan (Huss, 1986). Artinya, bila TVB sudah terbentuk dalam jumlah yang nyata, maka produk sudah mengalami perubahan mutu yang mengarah ke pembusukan. Hasil pengamatan TVB selama proses fermentasi sosis ikan terlihat pada Tabel 4. Bila dikaitkan dengan batas nilai TVB ikan segar, yaitu $30-40 \mathrm{mgN} \%$ (Connell, 1975), maka pada fermentasi $10^{\circ} \mathrm{C}$ perlakuan $L$. plantarum dan $L$. fermentum mencapai batas pada hari ke-8, sedangkan pada $20^{\circ} \mathrm{C}$, kedua perlakuan telah melampaui batas kesegaran pada hari ke-6. Pada $30^{\circ} \mathrm{C}$, perlakuan campuran bakteri memproduksi TVB di atas batas tersebut pada hari ke-2. Setelah itu produksi TVB terus berkembang hingga mencapai $67 \mathrm{mgN} / 100 \mathrm{~g}$ untuk $L$. plantarum dan $L$. fermentum. Keadaan ini tidak menguntungkan karena pada aplikasinya di lapangan, bila setelah proses fermentasi selesai, sosis tidak disimpan pada suhu rendah (misalnya pada penjualan eceran), maka jumlah TVB akan meningkat dengan cepat.

\section{Mutu Organoleptik}

Pengamatan mutu organoleptik hanya dilakukan terhadap rasa dan kekenyalan karena kedua parameter itulah yang sangat mungkin dipengaruhi oleh jenis bakteri maupun suhu fermentasi. Hasil pengamatan menunjukkan bahwa untuk ketiga jenis bakteri, pada suhu $10^{\circ} \mathrm{C}$ skor tertinggi untuk kekenyalan $(4,1)$ dan rasa $(2,8)$ tercapai pada hari ke 4 , sedangkan pada suhu $20^{\circ} \mathrm{C}$ skor tertinggi $(4,1$ untuk kekenyalan dan 2,5 untuk rasa) telah tercapai pada hari ke-2. Setelah itu, proses deteriorasi tampaknya telah berlangsung. Pada saat itu diperkirakan terjadi pemecahan senyawa-senyawa baik protein, karbohidrat maupun lemak, sehingga meng. hasilkan senyawa-senyawa yang menurunkan nilai rasa. Fermentasi pada $30^{\circ} \mathrm{C}$ memberikan pola yang agak berbeda. Walaupun kekenyalan terbaik $(3,6)$ telah tercapai pada hari ke-2, namun

Tabel 4. Kadar TVB (mgN/100g) sosis ikan selama proses fermentasi.

Table 4. TVB values ( $\mathrm{mgN} / 100 \mathrm{~g})$ of fish sausage during fermentation process.

\begin{tabular}{|c|c|c|c|c|}
\hline $\begin{array}{c}\text { Perlakuan } \\
\text { (Treatment) }\end{array}$ & Hari (Day-2) & Hari (Day-4) & Hari (Day-6) & Hari (Day-8) \\
\hline \multicolumn{5}{|l|}{$10^{\circ} \mathrm{C}$} \\
\hline $\mathrm{P}$ & $25.09 \pm 0.01^{\mathrm{ac}}$ & $27.14 \pm 0.02^{\mathrm{a}}$ & $26.87 \pm 0.00^{\mathrm{a}}$ & $35.14 \pm 7.06^{\mathrm{ab}}$ \\
\hline $\mathrm{F}$ & $28.45 \pm 0.01^{\mathrm{ab}}$ & $31.00 \pm 0.00^{\mathrm{b}}$ & $34.24 \pm 0.02^{\mathrm{b}}$ & $41.99 \pm 0.13^{\mathrm{a}}$ \\
\hline $\mathrm{PF}$ & $24.80 \pm 0.00^{\mathrm{ac}}$ & $23.86 \pm 0.07^{\mathrm{c}}$ & $23.90 \pm 0.00^{c}$ & $30.29 \pm 0.54^{\mathrm{b}}$ \\
\hline \multicolumn{5}{|l|}{$20^{\circ} \mathrm{C}$} \\
\hline$P$ & $30.57 \pm 0.03^{\mathrm{b}}$ & $30.66 \pm 0.00^{d}$ & $34.70 \pm 0.00^{\mathrm{d}}$ & $38.17 \pm 1.88^{\mathrm{ab}}$ \\
\hline $\mathrm{F}$ & $25.17 \pm 0.00^{\mathrm{ac}}$ & $34.63 \pm 0.03^{\mathrm{e}}$ & $44.13 \pm 0.00^{\mathrm{e}}$ & $38.96 \pm 0.71^{\mathrm{ab}}$ \\
\hline PF & $36.80 \pm 0.00^{d}$ & $27.09 \pm 0.00^{a}$ & $26.46 \pm 0.08^{f}$ & $37.16 \pm 1.46^{\mathrm{ab}}$ \\
\hline \multicolumn{5}{|l|}{$30^{\circ} \mathrm{C}$} \\
\hline $\mathrm{P}$ & $36.80 \pm 0.00^{\mathrm{d}}$ & $48.42 \pm 0.03^{f}$ & $48.27 \pm 0.10^{\mathrm{g}}$ & $49.97 \pm 3.07^{\mathrm{c}}$ \\
\hline $\mathrm{F}$ & $24.30 \pm 0.00^{c}$ & $37.09 \pm 0.00^{\mathrm{g}}$ & $48.42 \pm 0.03^{\mathrm{h}}$ & $67.58 \pm 2.13^{\mathrm{c}}$ \\
\hline $\mathrm{PF}$ & $48.92 \pm 5.32^{\mathrm{e}}$ & $49.56 \pm 0.00^{\mathrm{h}}$ & $48.37 \pm 0.02^{\mathrm{h}}$ & $41.03 \pm 11.88^{\mathrm{ab}}$ \\
\hline
\end{tabular}

P: L. plantarum, F: L.fermentum, PF: spesies campuran/ mixed species

Nilai dalam kolom diikuti huruf superskrip yang sama tidak berbeda nyata pada P:0,05/ Values in column followed by the same superscripts are not significantly different at P:0.05 
Tabel 5. Nilai organoleptik (skor) sosis ikan selama proses fermentasi.

Table 5. Organoleptic scores of fish sausage during fermentation process.

\begin{tabular}{|c|c|c|c|c|c|c|c|c|}
\hline \multirow{2}{*}{$\begin{array}{l}\text { Perlakuan } \\
\text { (Treatment) }\end{array}$} & \multicolumn{4}{|c|}{ Kekenyalan (Texture) } & \multicolumn{4}{|c|}{ Rasa (Flavor) } \\
\hline & $\begin{array}{c}\text { Hari-2 } \\
(\text { Day-2) }\end{array}$ & $\begin{array}{l}\text { Hari-4 } \\
(\text { Day-4) }\end{array}$ & $\begin{array}{l}\text { Hari-6 } \\
(\text { Day-6) }\end{array}$ & $\begin{array}{l}\text { Hari-8 } \\
(\text { Day-8) }\end{array}$ & $\begin{array}{c}\text { Hari-2 } \\
(\text { Day-2) }\end{array}$ & $\begin{array}{l}\text { Hari-4 } \\
(\text { Day-4) }\end{array}$ & $\begin{array}{c}\text { Hari-6 } \\
(\text { Day-6) }\end{array}$ & $\begin{array}{l}\text { Hari-8 } \\
(\text { Day-8) }\end{array}$ \\
\hline
\end{tabular}

$10^{\circ} \mathrm{C}$

$\begin{array}{ccccccccc}\mathrm{P} & 4.3 \pm 1.1^{\mathrm{a}} & 3.8 \pm 0.98^{\mathrm{ab}} & 3.0 \pm 0.8^{\mathrm{ac}} & 3.3 \pm 0.9^{\mathrm{a}} & 2.4 \pm 0.5^{\mathrm{a}} & 2.8 \pm 0.8^{\mathrm{a}} & 1.7 \pm 0.5^{\mathrm{a}} & 2.3 \pm 0.5^{\mathrm{ab}} \\ \mathrm{F} & 3.9 \pm 1.3^{\mathrm{a}} & 4.1 \pm 0.7^{\mathrm{a}} & 3.9 \pm 1.1^{\mathrm{b}} & 3.4 \pm 1.0^{\mathrm{a}} & 2.4 \pm 0.5^{\mathrm{a}} & 2.4 \pm 0.8^{\mathrm{a}} & 1.9 \pm 0.4^{\mathrm{a}} & 2.1 \pm 0.4^{\mathrm{a}} \\ \mathrm{PF} & 3.8 \pm 1.3^{\mathrm{a}} & 4.1 \pm 0.7^{\mathrm{a}} & 3.7 \pm 0.9^{\mathrm{b}} & 3.3 \pm 0.9^{\mathrm{ac}} & 2.4 \pm 0.5^{\mathrm{a}} & 2.5 \pm 0.7^{\mathrm{a}} & 2.0 \pm 0.0^{\mathrm{a}} & 2.1 \pm 0.4^{\mathrm{a}}\end{array}$

$20^{\circ} \mathrm{C}$

\begin{tabular}{|c|c|c|c|c|c|c|c|c|}
\hline $\mathrm{P}$ & $4.1 \pm 0.5^{\mathrm{a}}$ & $3.2 \pm 1.0^{\mathrm{ab}}$ & $3.3 \pm 0.5^{\mathrm{ab}}$ & $2.4 \pm 0.5^{\mathrm{b}}$ & $2.4 \pm 0.5^{\mathrm{a}}$ & $2.1 \pm 0.4^{\mathrm{a}}$ & $1.8 \pm 0.5^{\mathrm{a}}$ & $2.3 \pm 0.5^{\mathrm{ab}}$ \\
\hline $\mathrm{F}$ & $3.9 \pm 0.4^{\mathrm{a}}$ & $3.3 \pm 1.2^{\mathrm{ab}}$ & $3.4 \pm 0.5^{\mathrm{ab}}$ & $2.6 \pm 0.5^{c}$ & $2.5 \pm 0.5^{\mathrm{a}}$ & $2.1 \pm 0.4^{\mathrm{a}}$ & $1.7 \pm 0.5^{\mathrm{a}}$ & $2.3 \pm 0.5^{\mathrm{ab}}$ \\
\hline & $3.9 \pm 0.9^{\mathrm{a}}$ & $3.5 \pm 1.2^{\mathrm{ab}}$ & $3.4 \pm 0.5^{\mathrm{ab}}$ & $3.0 \pm 1.0^{\mathrm{a}}$ & $2.4 \pm 0.5^{\mathrm{a}}$ & $2.1 \pm 0.4^{\mathrm{a}}$ & $1.9 \pm 0.7^{\mathrm{a}}$ & $2.3 \pm 0.5^{\mathrm{ab}}$ \\
\hline
\end{tabular}

$30^{\circ} \mathrm{C}$

$\begin{array}{ccccccccc}\mathrm{P} & 3.2 \pm 1.5^{\mathrm{a}} & 3.0 \pm 0.8^{\mathrm{b}} & 2.4 \pm 0.5^{\mathrm{c}} & 2.9 \pm 0.7^{\mathrm{a}} & 2.4 \pm 0.5^{\mathrm{a}} & 2.5 \pm 0.6^{\mathrm{a}} & 3.0 \pm 0.5 \mathrm{~b} & 2.7 \pm 0.3^{\mathrm{b}} \\ \mathrm{F} & 3.3 \pm 1.6^{\mathrm{a}} & 3.3 \pm 1.1^{\mathrm{ab}} & 3.0 \pm 0.0^{\mathrm{ac}} & 2.9 \pm 0.7^{\mathrm{a}} & 2.4 \pm 0.5^{\mathrm{a}} & 2.4 \pm 0.5^{\mathrm{a}} & 3.0 \pm 0.0^{\mathrm{b}} & 2.5 \pm 0.4^{\mathrm{ab}} \\ \mathrm{PF} & 3.6 \pm 1.3^{\mathrm{a}} & 3.1 \pm 1.6^{\mathrm{ab}} & 3.0 \pm 0.0^{\mathrm{a}} & 3.0 \pm 0.6^{\mathrm{a}} & 2.4 \pm 0.5^{\mathrm{a}} & 2.4 \pm 0.6^{\mathrm{a}} & 3.0 \pm 0.7^{\mathrm{b}} & 2.4 \pm 0.4^{\mathrm{b}}\end{array}$

P: L. plantarum, F: L.fermentum, PF: spesies campuran/ mixed species

Nilai dalam kolom diikuti huruf superskrip yang sama tidak berbeda nyata pada P:0,05/ Values in column followed by the same superscripts are not significantly different at P:0.05.

rasa terbaik $(3,0)$ baru tercapai pada hari ke-6 (Tabel 5). Tidak diketahui senyawa apa yang menyebabkan rasa enak selain rasa asam, yang terdeteksi oleh panelis, yang terbentuk setelah pembentukan asam laktat. Sangat boleh jadi senyawa ini adalah senyawa hasil pemecahan protein yang didorong pembentukannya oleh lebih aktifnya enzim proteolitik karena meningkatnya $\mathrm{pH}$ akibat pembentukan senyawasenyawa amin.

Berdasarkan nilai organoleptik yang diperoleh, tampaknya panelis tidak dapat membedakan pengaruh jenis bakteri terhadap rasa dan kekenyalan produk. Oleh karena itu, penggunaan campuran bakteri yang dimaksudkan untuk mengurangi rasa asam atau untuk mendapatkan rasa terbaik ternyata tidak efektif.

\section{KESIMPULAN DAN SARAN}

1. Berdasarkan hasil pengamatan jumlah bakteri asam laktat, produksi asam laktat, dan nilai organoleptik, fermentasi sosis ikan lebih baik dilakukan pada suhu $10-20^{\circ} \mathrm{C}$, yang memerlukan waktu sekitar 4 hari. Pada suhu $30^{\circ} \mathrm{C}$, puncak fermentasi telah tercapai pada hari ke2 , tetapi laju perkembangan TVB sangat cepat.

2. Penggunaan bakteri dengan spesies campuran (antara L. fermentum dengan L. plantarum) tidak memberikan pengaruh berbeda dalam hal jumlah asam laktat yang diproduksi, $\mathrm{pH}$, dan nilai organoleptik, dibandingkan dengan penggunaan $L$. plantarum secara terpisah.

3. Bila digunakan bakteri asam laktat spesies tunggal, disarankan menggunakan L. planta- 
rum karena L. fermentum kecepatan fermentasinya sangat rendah.

\section{DAFTAR PUSTAKA}

Baran, W.C. and K.E. Stevenson. 1975. Survival of selected pathogens during processing of a fermented turkey sausage. J. of Fd.Sci.40:618-620

Connell, J.J. 1975. Control of fish quality: Methods of assessing and selecting for quality. Fishing News (Books) Ltd., Surrey, England: 107-132

Frazier, W.C. and D.C. Westhoff. 1979. Food microbiology. Tata McGraw Hill Publishing Co. New Delhi. $587 \mathrm{p}$.

Huss, H.H. 1986. Fresh fish quality and quality changes: Assessment of fish quality. FAO/DANIDA: FI/GCP/INT/292/DEN: 59-71

Indriati, N., H.E. Irianto, N. Haq dan Suparno. 1994.
Penentuan suhu inkubasi pada pembuatan sosis ikan fermentasi dengan menggunakan starter campuran $L$. plantarum dan L.fermentum. J. Penel. Pascapanen Perik. 78:66-71

Jay, J.M. 1978. Modern Food Microbiology. Van Nostrand Reinhold Co., N.Y. 479 p.

Smith, J.L.; and S.A. Palumbo. 1983. Use of starter cultures in meats. J.of Fd. Protection. Vol. 46 (11):997-1006

Stanton, W.R.; and Q.L. Yeoh. 1977. Low salt fermentation method for conserving trash fish waste under SE Asean condition. Proc. Conference on processing and marketing tropical fish. TPI, London: $277-282$

Tanaka, N.; E. Traisman, M.H. Lee; R.G. Cassens, and E.M. Foster. 1980. Inhibition of botulinum toxin formation in bacon by acid development. J. Food Protection 43:450-457. 